Krehl, W. A, and Strong, F. M. (1944). J. biol. Chem. 156, 1.

Kuhn, R., György, P. and Wagner-Jauregg, T. (1933). Ber. dtsch. chem. Ges. 66, 576.

Lohmann, K. and Schuster, P. $(1937,1)$. Naturwissenschaften, 25, 26.

Lohmann, K. and Schuster, P. (1937, 2). Biochem. Z. 294, 188.

Luckey, 'T. D., Teply, L. J. and Elvehjem, C. A. (1944). Science, 100, 201.

MeHenry, E. W. and Gavin, G. (1941). J. biol. Ohem. 138, 471.

Melnick, D. and Field, H. (1942, 1). J. Nutrit. 24, 131.

Melnick, D. and Field, H. (1942, 2). J. Nutrit. 24, 139.

Najjar, V. A. and Holt, L. E. (1940). Johns Hopk. Hosp. Bull. 67, 107.

Najjar, V. A. and Holt, I. F. (1941). Science, 93, 20.

Najjar, V. A. and Holt, L. E. (1942). Johns Hopk. Hosp. Bull. 70, 329.

Najjar, V. A., White, B. and Scott, D. B. M. (1944). Johns Hopk. Hosp. Bull. 74, 378.

Perlzweig, W. A., Levy, E. D. and Sarret, H. P. (1940). J. biol. Chem. 136, 729.

Platt, B. S. (1938). Trans. R. Soc. trop. Med. Hyg. 31, 493.

Platt, B.S. and Lu, G. D. (1935). Proc. physiol. Sec. 3rd gen. Conf. Chin. med. Ass.

Platt, B. S. and Lu, G. D. (1936). Quart. J. Med. 5, 355.

Platt, B. S. and Webb, R. A. (1946). Proc. Nutr. Soc. 4, 132.

Price, D. and Pickel, F. D. (1941). J. Amer. chem. Soc. 63, 1067.

Quastel, J. H. (1946). Proc. Nutr. Soc. 4, 92.

Reid, D. F., Lepkovsky, S., Bonner, D. and Tatum, E. L. (1944). J. biol. Chem. $155,299$.

Robinson, F. A. (1946). Proc. Nutr. Soc. 4, 106.

Ruffin, J. M., Cayer, D, and Perlzweig, W. A. (1944). Gastroenterology, 3, 340. Schlenk, F. and Snell, E. E. (1945). J. biol. Chem. 157, 425.

Scott, M. L., Norris, L. C., Heuser, G. F. and Bruce, W. F. (1945). J. biol. Chem. $158,291$.

Shils, M. E., Day, H. G. and MeCollum, E. V. (1941). J. biol. Chem. 139, 145.

Smith, D. T., Ruffin, J. M. and Smith, S. G. (1937). J. Amer. med. Ass. 109, 2054.

Snell, E. E. and Strong, F. M. (1939). Industr. Engng Chem., Anal. Ed. 11, 346.

Snell, E. E. and Wright, L. D. (1941). J. biol. Chem. 139, 675.

Swaminathan, M. (1938). Nature, Lond., 141, 830.

Swaminathan, M. (1944). Indian J. med. Res. 32, 39 ,

Thompson, R. H. and Johnson, R. F. (1934). Chem. and Ind. 53, 1024.

Thompson, R. H. and Johnson, R. E. (1935). Biochem. J. 29, 694.

Todd, A. R. and Bergel, F. (1937). J. chem. Soc. p. 364.

Waisman, H. A. and Elvehjem, C. A. (1941). Industr. Engng Chem., Anal. Ed. 13,221 .

Wang, Y. L. and Harris, L. J. (1939). Biochem. J. 33, 1356.

Wang, Y. L. and Kodicek, E. (1943). Biochem. J. 37, 530.

Wang, Y. L. and Kodicek, E. (1946). Biochem. J. In press.

Wang, Y. L. and Yudkin, J. (1940). Biochem. J. 34, 343.

Williams, R. D., Mason, H. L. and Wilder, Z. M. (1943). J. Nutvit. 25, 71.

Williams, R. J. (1943). Advanc. Enzymol. 3, 253.

Williams, R. R. (1936). J. Amer. chem. Soc. 58, 1063.

Williams, R. R. and Cline, J. K. (1936). J. Amer. chem. Soc. 58, 1504.

Wills, L. (1946). Proc. Nutr. Soc. 4, 140.

Windaus, A., Tschesche, R. and Grewe, R. (1935). Hoppe-Seyl. Z. 237, 98.

Woolley, D. W., Waisman, H. A. and Elvehjem, C. A. (1939). J. Amer. chem. Soc. 61, 977.

\title{
Role of Members of the Vitamin B Complex in Enzyme Systems
}

Dr. J. H. Quastel (Agricultural Research Council Unit of Soil Metabolism, University College, Cardiff)

Aneurin

The work of Peters and his colleagues (Gavrilescu, Meiklojohn, Passmore and Peters, 1932; Passmore, Peters and Sinclair, 1933; Peters and Sinclair, 1933; Sinclair, 1933; Thompson, 1934; Peters, Rydin and Thompson, 1935; Kinnersley, O'Brien and Peters, 1935; Rydin 
1935) was the first to indicate the highly important relationship which exists between vitamin $B_{1}$ and pyruvate metabolism. They showed that in vitamin $B_{1}$ deficiency the brain suffers an inability to burn glucose or lactic acid at its normal rate and that the diminished rate of brain respiration in presence of glucose or lactate is increased to the normal level by the addition to the isolated tissue of a small quantity of the vitamin. The chemical upset in polyneuritis was shown ultimately to be concerned with a faulty utilization of pyruvic acid which had been found to accumulate in the tissues as a result of deprivation of vitamin $B_{1}$.

The next important step was the discovery by Lohmann and Schuster (1937) that co-carboxylase, the substance found by Auhagen (193I, 1932) to be essential for the activity of yeast carboxylase, was aneurin pyrophosphate, This substance, rather than aneurin itself, was then found to be the co-enzyme of pyruvate oxidation (Lipmann, 1937; Barron and Lyman, 1939; Long and Peters, 1939,1,2; Banga, Ochoa and Peters, 1939,1,2,3; Ochoa, 1939; Silverman and Werkman, 1939). It soon became clear that phosphorylation of aneurin speedily takes place in animal tissues, in yeast and in bacteria. Later investigations all emphasized the important role played by aneurin pyrophosphate in changes undergone by pyruvic acid in the living cell. A summary of such changes, all known to be catalysed by aneurin pyrophosphate, is shown in Table 1. The changes involve decarboxylations, oxidations, condensations and synthetic transformations.

TABLE 1

Enzymo Changes Undergone by Pyrtuio Acid and Catalysed by Aneurin Pyrophosphate

\begin{tabular}{|c|c|c|c|}
\hline $\begin{array}{l}\text { Function of } \\
\text { enzyme system }\end{array}$ & $\begin{array}{l}\text { Biological } \\
\text { source }\end{array}$ & End products & Reference \\
\hline Carboxylation & $\begin{array}{l}\text { Yeast } \\
\text { Animal } \\
\text { Bacteria }\end{array}$ & $\begin{array}{l}\text { Acetaldehyde, } \mathrm{CO}_{2} \\
\text { Acetylmethyl- } \\
\text { carbinol, } \mathrm{CO}_{2} \\
\text { Acetylmethyl- } \\
\text { carbinol, } \mathrm{CO}_{2}\end{array}$ & $\begin{array}{l}\text { Lohmann and Schuster(1937) } \\
\text { Green, Westerfeld, Vennes- } \\
\text { land and Knox (1942) } \\
\text { Silverman and Werkman } \\
(1941)\end{array}$ \\
\hline Oxidation & $\begin{array}{l}\text { Bacteria } \\
\text { Animal }\end{array}$ & Acetic acid, $\mathrm{CO}_{2}$ & $\begin{array}{l}\text { Lipmann (1937) } \\
\text { Long (1938); Peters and col- } \\
\text { leagues }\end{array}$ \\
\hline Dismutation & $\begin{array}{l}\text { Bacteria } \\
\text { Bacteria }\end{array}$ & $\begin{array}{l}\text { Lactic acid, acetic } \\
\text { acid, } \mathrm{CO}_{2} \\
\text { Formic acid, acetic } \\
\text { acid }\end{array}$ & $\begin{array}{l}\text { Silverman and Werkman } \\
(1939) \text {; Krebs (1937) } \\
\text { Barron and Lyman (1939) }\end{array}$ \\
\hline $\begin{array}{l}\text { Condensations } \\
\text { and syntheses }\end{array}$ & $\begin{array}{l}\text { Animal } \\
\text { Animal } \\
\text { Animal }\end{array}$ & $\begin{array}{l}\text { Citric acid } \\
\text { Carbohydrate } \\
\text { Acetylcholine }\end{array}$ & $\begin{array}{l}\text { Sober, Lipton and Elvehjem } \\
\text { (1940) } \\
\text { Barron, Lyman, Lipton and } \\
\text { Goldinger (1941, 1, 2) } \\
\text { Mann and Quastel }(1940)\end{array}$ \\
\hline
\end{tabular}

More than one enzyme is involved in these changes which affect pyruvic acid, for the carboxylase responsible for the anaerobic breakdown of pyruvic acid to acetaldehyde is clearly different from the enzyme engaged in the oxidation of pyruvic acid. Since the same co-enzyme is vot. 4, 1946] 
involved, it has to be recognized that there must be several specific proteins capablo of forming, with aneurin pyrophosphate, separate enzyme systems capable of activating pyruvic acid. This, it will be seen, is a characteristic feature of members of the vitamin B complex so far investigated.

The fact that aneurin pyrophosphate catalyses many of the transformations undergone by pyruvic acid is reflected in the stimulatory effects of the vitamin on many metabolic changes which involve pyruvic acid as an intermediate. For example, the respiration of bacteria grown on media deficient in aneurin, in presence of glucose, glycerol, sodium lactate, sodium succinate or sodium propionate is greatly increased by the addition of aneurin (Quastel and Webley, 1941). In the absence of added aneurin, pyruvic acid accumulates during the oxidation of these substances; in its presence there is little or no such accumulation. Similarly the synthesis, in the rat deprived of aneurin, of citric acid, which is known from the work of Martius and Knoop (1937) to break down in the liver to $\alpha$-ketoglutaric acid and then to pyruvic acid, is greatly increased by the application of aneurin (Sober, Lipton and Elvehjem, 1940). The formation in kidney slices of carbohydrate, shown by Benoy and Elliott (1937) to be increased by the presence of pyruvate, has been shown by Barron, Lyman, Lipton and Goldinger $(1941,1,2)$ to be markedly improved by addition of tho vitamin to the tissue when this is derived from rats deprived of aneurin. Again, the synthesis of acetylcholine in fresh brain tissue, shown by Quastel, Tennenbaum and Wheatley (1936) to be dependent upon the presence of pyruvic acid, is accelerated on application of the vitamin to isolated polyneuritic brain tissue.

It was early recognized that magnesium ions catalyse the decarboxylation and oxidation of pyruvic acid in presence of aneurin pyrophosphate. Green, Herbert and Subrahmanyan (1940, 1, 2), working with a purified yeast carboxylase preparation, claim that the enzyme contains magnesium as well as aneurin pyrophosphate as an integral part of its structure. Kubowitz and Lüttgens (1941) state that their purest preparation of carboxylase contained per g. mol. $1 \mathrm{~g}$. atom magnesium, $1 \mathrm{~g}$. molecule aneurin pyrophosphate and $75,000 \mathrm{~g}$. protein. Whether or not magnesium forms an integral part of the enzyme structure, this cation evidently plays a significant role in the mechanism whereby pyruvate undergoes its transformations. This role is not understood, any more than that of aneurin pyrophosphate itself. Magnesium plays an essential part in many phosphorylation mechanisms and seems to be uniquely connected with them. The part played by magnesium in the catalyses of aneurin may point to a phosphorylation process as being an essential reaction in these processes. Lipmann (1941) visualizes the first change of pyruvate to be an oxidative phosphorylation to acetylphosphate which in turn yields its phosphate to adenylic acid to form acetic acid and adenylpyrophosphate. The oxidation to acetylphosphate he considers to be due to the action of a flavoprotein. Still (1941) finds that oxidation of pyruvate with Bact. coli is coupled with a phosphorylation of adenylic acid (see also Ochoa, 194I).

Adenylpyrophosphate appears to play in aneurin metabolism a part as important as in many other metabolic changes. Results secured by 
Weil-Malherbe (1939) show that, with a yeast extract, the synthesis of aneurin pyrophosphate from aneurin proceeds only through the mediation of adenylpyrophosphate. Lipton and Elvehjem (1941) also conclude that adenylpyrophosphate and aneurin react in presence of an alkali washed yeast to yield aneurin pyrophosphate. The enrichment of bacterial cells in adenylpyrophosphate has been invoked by Quaste] and Webley (1942) to account for the accelerative effects of incubating the bacteria with magnesium ions or adenylic acid on their subsequent oxidations in presence of aneurin.

It is worth pointing out that potassium ions have been found very greatly to increase the accelerative effects of magnesium ions in bacterial oxidations (Quastel and Webley, 1942), a phenomenon which has been held due to permeability changes induced by potassium.

Aneurin is not concerned only with transformations of pyruvate (see Table 2). According to Barron et al. $(1941,1,2)$ the oxidation of $\alpha$-keto. glutarate, a molecule of great importance in transaminations, demand

TABLE 2

Changes of Substances other than Pyruvic Actd Catalysed by Aneurin

\begin{tabular}{|c|c|c|c|}
\hline Substance & Enzyme system & End produets & Reference \\
\hline $\begin{array}{c}\alpha \text {-Ketobutyric acid } \\
", \\
\alpha \text {-Ketovaleric acid } \\
\alpha \text {-Ketoglutaric acid }\end{array}$ & $\begin{array}{l}\text { Carboxylase, yeast } \\
\text { Oxidase, animal } \\
\text { Carboxylase } \\
\text { condensation } \\
\text { Carboxylase, yeast } \\
\text { Carboxylase } \\
\text { Oxidase } \\
\text { Oxidase }\end{array}$ & $\begin{array}{l}\text { Corresponding } \\
\text { aldehyde } \\
\text { Propionic acid } \\
\text { Propioin } \\
\text { Corresponding } \\
\text { aldehyde } \\
\text { Succinic semi- } \\
\text { aldehyde } \\
\text { Succinic acid } \\
\mathrm{CO}_{2}\end{array}$ & $\begin{array}{l}\text { Long and Peters } \\
\text { (1939) } \\
\text { Long and Peters } \\
\text { (1939) } \\
\text { Green et al. (1942) } \\
\text { Long and Peters } \\
\text { (1939) } \\
\text { Green et al. (1942) } \\
\text { Barron et al. } \\
(1941,1,2) \\
\text { Quastel and Webley } \\
\text { (1941) }\end{array}$ \\
\hline
\end{tabular}

the participation of aneurin. This oxidase differs from pyruvate oxidase, since some bacteria which oxidize pyruvate at great speed apparently do not utilize $\alpha$-ketoglutarate.

A molecule quite distinct from the $\alpha$-ketonic acids whose oxidation requires the participation of aneurin and magnesium is acetic acid (Quastel and Webley, 1941, 1942). The rate of oxidation of this substance to $\mathrm{CO}_{2}$ by bacteria grown on an aneurin deficient medium is enormously enhanced by the addition of the vitamin. No evidence could be secured that pyruvic acid is an intermediate in this oxidation and the facts indicate that yet another enzyme, acetic acid oxidase, requires the co-operation of aneurin pyrophosphate and magnesium.

voL. 4, 1946] 
Aneurin can be broken down by specific enzymes found in the organs of certain fishes, especially fresh water fish (Sealock, Livermore and Evans, 1943). This was discovered when it was found that foxes fed on raw fish developed polyneuritis.

Decarboxylation of oxalo-acetic acid to pyruvic acid does not require aneurin, but magnesium seems to be essential (Krampitz and Werkman, 1941; Quastel and Webley, 1942); neither is aneurin required in transaminations involving pyruvic or oxalo-acetic acid.

\section{Nicotinic Acid}

This substance, first isolated from rice polishings by Japanese workers (Suzuki, Shimamura and Odake, 1912) and in the following year from yeast by Funk $(1913,1,2)$, was thrown into prominence by the discovery by Warburg and Christian (1934, 1935, 1936; see also Warburg, Christian and Griese, 1935) that nicotinamide forms part of a co-enzyme involved in hexosemonophosphate oxidation. A little later Euler, Albers and Schlenk $(1936,1)$ obtained nicotinamide from co-zymase, the co-enzyme of alcoholic fermentation. The work of Warburg and Christian, and of Euler, Albers and Schlenk $(\mathbf{1 9 3 6}, \mathbf{2})$ showed that both these enzymes are adenine-nicotinamide-dinucleotides, the former co-enzyme containing three phosphoric acid groups and the latter two. The type of linkage between nicotinamide and the rest of the molecule in the nucleotides was established by Karrer, Schwarzenbach, Benz and Solmssen (1936). The two nucleotides may be written as follows:

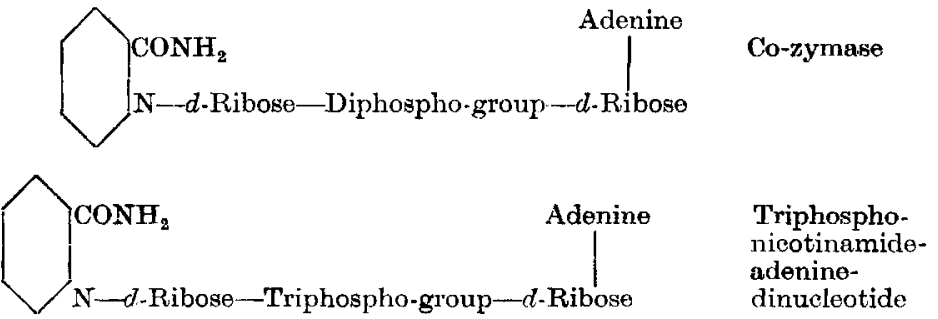

Kohn and Elvehjem (1936) prepared a liver concentrate which cured chick dermatitis and dog blacktongue, and Elvehjem and his colleagues (Elvehjem, Madden, Strong and Woolley, 1937, 1938; Elvehjem, Woolley, Strong and Madden, 1938) later isolated nicotinamide from such a concentrate and showed the activity of nicotinic acid in curing blacktongue. Knight (1937) was able to demonstrate that nicotinic acid is an essential growth factor for Staphylococcus. These facts made clear the importance of nicotinic acid as a nutritional factor and focussed interest on the part played by it as a constituent of co-enzymes.

The work of Warburg and his co-workers (Warburg et al., 1935; Warburg and Christian, 1936) showed that the co-enzyme of hexosemonophosphate oxidation undergoes reduction during the enzyme reaction, the hexosemonophosphate becoming oxidized. The reduced form of the co-enzyme is not autoxidizable but may be oxidized in a variety of ways. The reversible oxidation and reduction of the co-enzyme accounts for its catalytic powers. Spectroscopic evidence made it clear that the 
nicotimamide part of the molecule is the seat of the oxido-reductive changes. Thus:<smiles>[R][n+]1cccc(C(N)=[PtH])c1</smiles>

Co-zymase, the diphospho-nicotinamide-adenine-dinucleotide is widely distributed and is a co-enzyme for a large variety of oxidative enzyme systems. The triphospho-dinucleotide acts as a co-enzyme for a smaller number of such systems.

The various specific proteins with each of which co-zymase combines reversibly are dehydrogenases capable of activating many substrates and accomplishing their oxidation. Reduced co-zymase is equally capable of combining in a reversible manner with the dehydrogenases, and activated substrates may oxidize the reduced co-enzyme, themselves undergoing reduction. Fquilibria are set up in the following ways:

Lactic dehydrogenase

$\begin{array}{lll}\text { Lactate }+ \text { co-zymase } & \longleftrightarrow & \text { Pyruvate }+ \text { reduced co-zymase } \\ \text { Ethyl alcohol + co-zymase } & \longleftarrow & \text { Acetaldehyde + reduced co-zymase }\end{array}$

Alcohol dehydrogenase

Owing to the fundamental fact that combination with the co-enzyme is not restricted to one dehydrogenase, the co-enzyme can act as a link between a variety of oxido-reductive systoms. This is shown in the following example:

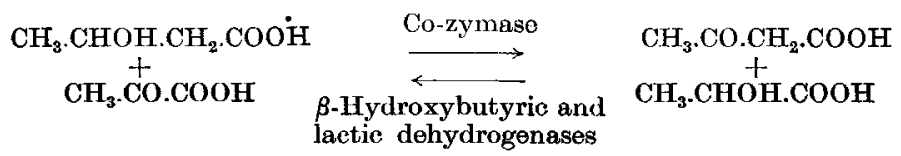

The extent to which these interactions will proceed depends upon the equilibrium constants between co-enzyme and the specific dehydrogenases combining with it and also on whether a product of interaction is removed from the equilibrium system by a secondary change.

It is, therefore, possible for co-zymase to institute in the cell a whole chain of reactions involving transfer of hydrogen from one molecule to another as long as the appropriate dehydrogenases are present. Its function is that of a middleman capable of receiving hydrogen from various substrates activated by different enzymes and passing it on to other substrates activated by their enzymes. It regulates the speed and passage of hydrogen in the cell and in this way helps to control the rates and courses of intracellular oxidations. A list of molecules whose oxidations and reductions are controlled in this way by co-zymase is shown in Table 3.

There is no reason to suppose that co-zymase and reduced co-zymase are any more than substrates for the dehydrogenases. Their affinities vor. 4,1946$]$ 
for a dehydrogenase are of the same order as those of the more familiar substrates, as in the case of alcohol dehydrogenase and acetaldehyde (Negelein and Wulff, 1937). They differ from such substrates, however, in their ability to combine with a large variety of dehydrogenases and are obviously so combined with the enzymes that they do not interfere

TABLE 3

Molmeules whose Oxidations and Rfouchons are Controlled by Co-zyMase

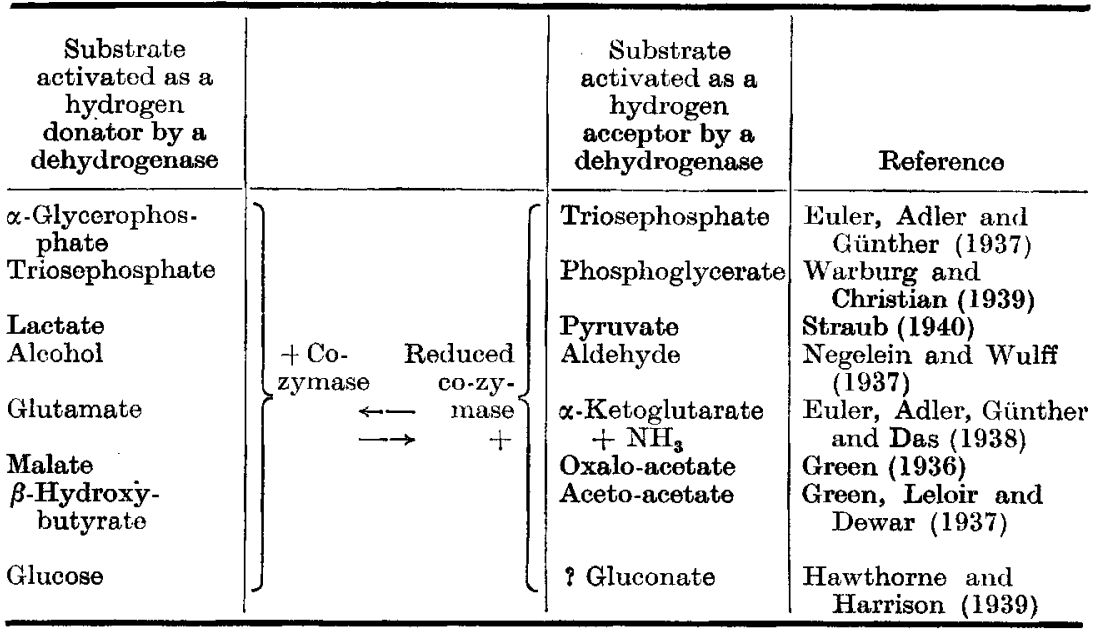

with the approach of the more familiar substrates. As will be shown later, reduced co-zymase must be capable of combination with, and activation by, still another class of enzyme, a flavoprotein. But here it passes its hydrogen to another nucleotide, iso-alloxazine-adonine-dinucleotide, which is a constituent of the flavoprotein.

Certain dismutations occur in the living cell whereby a molecule undergoes self oxidation and reduction as, for instance, when triosephosphate is transformed into a mixture of $\alpha$-glycerophosphate and phosphoglycerate. It was thought at one time that one enzyme only is involved, but it is now known that two dehydrogenases are involved, each sharing co-zymase (Quastel and Wheatley, 1938).

The part played by nicotinamide as a constituent of dehydrogenase co-enzymes is at present the only one known in which nicotinic acid is concerned in the essential metabolic events of the cell. The studies of Elvehjem, Woolley et al. (1938) which show that, out of 20 compounds investigated, only those exhibit antiblacktongue potency which form nicotinic acid or its amide by oxidation or by hydrolysis, and the fact that whilst most micro-organisms need nicotinic acid some require co-zymase itself, all lead to the belief that the importance of nicotinic acid lies in its necessity for building up the co-enzymes of dehydrogenases.

Braunstein and Asarkh (1945) have recently pointed out a possible important connexion of co-zymase with amino-acid oxidations. They show that a variety of natural ( $l$-) amino-acids may undergo vigorous 
oxidation in presence of tissue suspensions by preliminary transamination in presence of $\alpha$-ketoglutaric acid to $l$-glutamic acid which is now re-oxidized to $\alpha$-ketoglutaric acid and ammonia by glutamic dehydrogenase in presence of co-zymase. Thus:

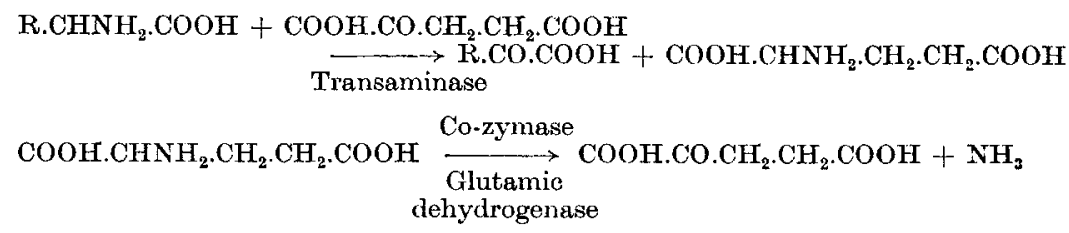

Although neither nicotinic acid nor nicotinamide can itself act as a coenzyme in dehydrogenase systems, the latter molecule may indirectly influence the kineties of isolated oxidizing systems. This is due to the fact that co-zymase is broken down by a nucleotidase in the tissues and this hydrolytic enzyme has been shown by Mann and Quastel (1941) to be inhibited specifically by nicotinamide. Nicotinamide in fact stimulates the respiration of isolated tissue systems because it inhibits the breakdown of co-zymase whose integrity is necessary for optimal respiration. It follows, too, that in the living cell, the presence of free nicotinamide may preserve the level of co-zymase, or even cause its enrichment, not necessarily by synthesis, but by interfering with a normal hydrolytic breakdown of the eo-enzyme.

\section{Riboflavin}

The isolation from yeast by Warburg and Christian $(1932,1933)$ of a conjugated protein which they called a "yellow enzyme" was followed by the isolation from egg white and milk by Kuhn, György and WagnerJauregg $(1933,1,2,3)$, and from whey by Ellinger and Koschara $(1933,1,2,3,1934)$, of a lactoflavin which seemed to be identical with the yellow compound associated with the yellow enzyme. György, Kuhn and Wagner-Jauregg (1934) showed that lactoflavin or riboflavin is identical with vitamin $B_{2}$. The demonstration that this flavin can undergo reductions and oxidations in biological systems served to focus attention on the possible part played by vitamin $B_{2}$ in respiratory systems.

A number of flavoproteins is now known to exist, each having specific catalytic powers in oxidative systems. The co-enzyme or prosthetic group associated with the specific protein involved, is usually iso-alloxazine-adenine-dinucleotide whose structure (Kuhn, Reinemund, Kaltschmitt, Strobele and Trischmann, 1935; Karrer, Sehöpp and Benz, 1935) has a remarkable similarity to that of the nicotinamide-adenine-dinucleotide:

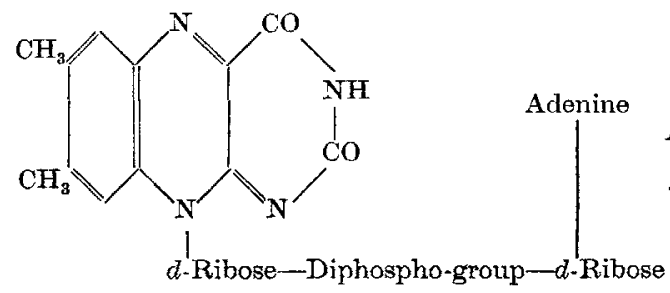

Iso-alloxazine-

-adenine-

-dinucleotide

voL. 4,1946$]$ 
The iso-alloxazine nucleus, like that of nicotinamide in co-zymase, is the seat of oxido-reductive changes. A list of flavoproteins having specific activating powers is shown in Table 4 . These enzymes appear

TABLE 4

Flavoproteins with Specific Activating Powers

\begin{tabular}{|c|c|c|c|}
\hline $\begin{array}{l}\text { Source } \\
\text { of flavo- } \\
\text { protein }\end{array}$ & Substrates affected & Enzyme system & Reference \\
\hline Yeast & $\left.\begin{array}{c}\text { Reduced co-zymase } \\
\text { Reduced triphospho- } \\
\text { nieotinamide-aden- } \\
\text { ine-dinucleotide }\end{array}\right\}$ & Diaphorase & $\begin{array}{l}\text { Euler and Hellström } \\
\quad(1938) \\
\text { Dowan and Green (1938) }\end{array}$ \\
\hline Heart & $\begin{array}{l}\text { Reduced triphospho-ni- } \\
\text { cotinamide-adenine- } \\
\text { dinucleotide }\end{array}$ & Diaphorase & Straub (1939) \\
\hline Yeast & $\begin{array}{l}\text { Triphospho - nicotin - } \\
\text { amide-adenine-dinu- } \\
\text { cleotide } \\
\text { Cytochrome }\end{array}$ & $\begin{array}{r}\text { Cytochrome } \\
\text { reductase }\end{array}$ & Haas et al. $(1940,1942)$ \\
\hline Kidney & d-Amino & $\begin{array}{l}d \text {-Amino-acid } \\
\text { oxidase }\end{array}$ & $\begin{array}{l}\text { Warburg and Christian } \\
\text { (1938) }\end{array}$ \\
\hline \multirow[t]{2}{*}{ Milk } & Aldehydes & $\left.\begin{array}{r}\text { Aldehyde } \\
\text { oxidase }\end{array}\right]$ & Ball (1939) \\
\hline & $\begin{array}{l}\text { Purines (hypo- } \\
\text { xanthine) } \\
\text { Reduced co-zymase }\end{array}$ & $\begin{array}{r}\text { Xanthine } \\
\text { oxidase }\end{array}$ & $\begin{array}{l}\text { Corran, Green et al. } \\
\quad(1939)\end{array}$ \\
\hline Kidney & $\left.\begin{array}{l}l \text {-Arnino-acids } \\
\text { Reduced co-zymaso }\end{array}\right\}$ & $\begin{array}{l}\text { l-Amino-acid } \\
\text { oxidase }\end{array}$ & $\begin{array}{l}\text { Green, Moore, Nocito } \\
\text { and Ratner (1944) }\end{array}$ \\
\hline Bacteria & Aceto-acetic acid & $\begin{array}{l}\text { Aceto-acetic } \\
\text { decarboxylase }\end{array}$ & Davies (1943) \\
\hline Bucteria & Pyruvic acid & $\begin{array}{l}\text { Pyruvic oxidation } \\
\text { system }\end{array}$ & Lipmann (1939) \\
\hline Yeast & Fumaric acid & Reductase & $\begin{array}{l}\text { Fischer and Fysenbach } \\
\text { (1937) }\end{array}$ \\
\hline
\end{tabular}

to be responsible for the oxidation of the reduced forms of the diphosphoand triphospho-nicotinamide-adenine-dinucleotides. Such enzymes are known as diaphorases. The long familiar xanthine- and aldehyde- oxidases also are flavoproteins, whilst the oxidation of amino-acids, whether $l$-or $d$-, demands the presence of similar enzymes (see also, however, Braunstein and Asarkh, 1945).

The flavin dinucleotides are for the most part firmly bound to their rospective proteins and are not easily dissociated, but $d$-amino-acid oxidase seems to be exceptional in being easily split into its components. At $p \mathrm{H} 8.5$ it dissociates to the extent of 90 per cent. and, although it behaves as a dissociated flavoprotein in solution, it precipitates out of solution as a conjugated protein. The reduced form of the oxidase does not appear to dissociate.

The activity of the flavoproteins can be very high. One molecule of heart-diaphorase flavoprotein, for example, will catalyse the oxidation of 8000 molecules of dihydro-co-zymase per minute by an oxidizing agent such as methylene blue (Straub, 1939).

The co-enzymes of diaphorase, aldehyde oxidase and $d$-amino-acid oxidase are identical, i.e., flavin-adenine-dinucleotide. Green, Moore, 
Nocito and Ratner (1944), however, note that the co-enzyme concerned with the flavoprotein responsible for the oxidation of the $l$-amino acids is not flavin-adenine-dinucleotide.

It should be pointed out that in the first flavoprotein isolated by Warburg and Christian (1932, 1933) (see also Theorell, 1934, 1935, 1937; Kuhn and Rudy, 1936), the prosthetic group was simply riboflavin phosphate, with relatively feeble catalytic activities. There is doubt as to whether this particular molecule functions as a co-enzyme in the living cell. It is now known (Klein and Kohn, 1940) that cells can synthesize flavin-adenine-dinucleotide from riboflavin both in vitro and in vivo (see also Trufanov, 1941). The work of Axelrod and Elvehjem (1941) shows that riboflavin deficiency leads to a diminution in flavoprotein content as measured by xanthine oxidase activity, and that riboflavin therapy administered to rats restores the xanthine oxidase activity to its normal value (Ochoa and Rossiter, 1939; Axelrod, Sober and Elvehjem, 1940; Rossiter, 1940).

The flavoproteins may be regarded as a special class of dehydrogenases. They activate their substrates, e.g., reduced nicotinamide-adeninedinucleotides, amino-acids, aldehydes and purines, and bring about a transference of hydrogen to the co-enzyme of the flavoproteins, i.e., usually flavin-adenine-dinucleotide. They work anaerobically in exactly the same way as the more familiar dehydrogenases.

The reduced flavoprotein is autoxidizable, and its oxidation is not inhibited by cyanide. Thus an oxidation catalysed by flavoprotein need not be sensitive to cyanide. The following is an example of a flavoprotein catalysed oxidation:

$\begin{array}{ccc}\text { Hexose monophosphate } & +\begin{array}{c}\text { triphospho-nicotinamide- } \\ \text { adenine-dinucleotide }\end{array} & \begin{array}{c}\text { phosphohexonic acid } \\ \text { Dehydrogenase }\end{array} \\ \begin{array}{c}\text { reduced triphospho- } \\ \text { nicotinamide-adenine- } \\ \text { dinucleotide } \\ \text { tinamide-adenine-di- } \\ \text { nucleotide }\end{array} & \rightarrow \begin{array}{c}\text { triphospho-nicotinamide } \\ \text { adenine-dinucleotide }\end{array} \\ \text { Reduced flavoprotein } & +\mathrm{O}_{2} & \begin{array}{c}+ \\ \text { reduced flavoprotein }\end{array}\end{array}$

Theorell $(1936,1,2)$, however, pointed out that the rate of oxidation of a flavoprotein at the oxygen tensions obtaining in living tissues is too slow to account for normal respiratory rates, and suggested that cytochrome may be involved in the re-oxidation of reduced flavoprotein in vivo. This would make a system catalysed by flavoprotein in the living cell sensitive to cyanide. Haas, Horecker and Hogness (1940) have now proved that the flavoprotein concerned with hexose monophosphate oxidation is indeed oxidized by the cytochrome system. Reduced flavoprotein is oxidized also by a dyestuff such as methylene blue, or by natural cell pigments such as pyocyanine. The reduction of these substances by dehydrogenase systems is made possible by the flavoproteins present.

With the cyanide sensitive respiratory systems in which cytochrome is involved, it seems most likely that flavoproteins play a fundamental part. Indeed, recent work on the mode and site of action of narcotics in respiratory systems suggests that the flavoprotein is the most voL. 4, 1946] 
susceptible link in the chain of oxidative events (Michaelis and Quastel, 1941).

\section{Nicotinamide and Iso-alloxazine.}

As has been shown both these substances form, when combined as adenine-dinucleotides, intracellular carriers in chains of oxido-reduction systems in the living cell. This appears to be their biological function independently of whether or not they form integral parts of enzyme structures. They allow a great varicty of oxidations to take place under anacrobic conditions. These facts fully confirm the conchusion, made for the first time by Quastel and Wooldridge (1929) from their work on bacterial growth, that intracellular carriers play an essential part in the metabolism of cells proliferating under anaerobic conditions.

\section{Pyridoxin}

This substance, known also as vitamin $B_{6}$ and adermin, has been synthesized (Harris and Volkers, 1939; Kuhn, Westphal, Wendt and Westphal, 1939).<smiles>O=CC1CN2CCC(CO)C1CC2</smiles>

It plays an important part in the nutrition of the rat and the chicken, and is now known to participate in certain enzyme reactions. There is a suggestion by Schlenk and Snell (1945) that pyridoxin is a factor in transamination. Recent work has shown that the vitamin is closely concerned with amino-acid decarboxylations and transaminations.

Enzymes concerned with decarboxylation, as well as a de-amination, of a variety of amino-acids have been studied by Woods and Trim (1942). Bacterial amino-acid decarboxylases were investigated by Gale and Epps $(1942,1,2,1943)$, who showed that under suitable growth conditions. specific enzymes are evolved which decarboxylate arginine, ornithine, histidine and lysine to the corresponding amines. These workers prepared a purified preparation of lysine decarboxylase from an acetone dried powder of Bacterium cadaveris, and found that this decarboxylates lysine to cadaverine, attacking only the laevo-isomer, and that a hitherto unidentified and widely distributed co-enzyme is required.

Gunsalus and Bellamy $(1944,1)$ have shown that cell suspensions of Streptococcus faccalis harvested on vitamin deficient media are unable to decarboxylate tyrosine, but acquire this function on addition of the vitamin. Gunsalus and Bellamy $(1944,2)$, and Gunsalus, Bellamy and Umbreit (1944) state that the activity of pyridoxal in the decarboxylation of tyrosine by dried Streptococcus faecalis from a vitamin deficient medium is greatly accelerated by the addition of adenylpyrophosphate. The results indicate that a phosphorylated derivative of pyridoxin is the co-enzyme of tyrosine decarboxylase, the phosphorylation taking place in the living cell at the expense of adenylpyrophosphate. An active co-enzyme may be prepared by treating pyridoxal with phosphoric acid in the cold. Baddiley and Gale (1945) have confirmed the finding that pyridoxal phosphate acts as a co-decarboxylase in the decarboxylation of $l$-tyrosine, 
$l$-lysine, $l$-arginine and $l$-ornithine, and that the co-enzyme may be prepared by incubation of pyridoxal with adenylpyrophosphate in presence of the enzyme of $S$. faecalis.

Lichstein, Gunsalus and Umbreit (1945) have now found that pyridoxal phosphate will act as a co-transaminase with glutamic and aspartic acids.

\section{Biotin}

This substance, whose structure was determined by du Vigneaud (1942) and his colleagues, is apparently essential for normal metabolism and is a growth factor for Rhizobia, fungi and insects.<smiles>O=C(O)CCCCC1CCC2NC=NC12</smiles>

Only the most vague suggestions have so far appeared as to its part in metabolic processes. According to Burk, Winzler and du Vigneaud (1941) it exercises differential effects upon the fermentation and respiration of yeast. Pilgrim and Elvehjem (1944) suggest an indirect effect of both biotin and pantothenic acid in pyruvate metabolism of rat liver.

Biotin occurs in a bound form in proteins (Miller, Lampen and Peterson, 1943), and avidin, the protein constituent of egg white which combines with biotin, has been obtained in a crystalline state (Pennington, Snell and Eakin, 1942). Synthetic and natural biotin have similar effects on rats treated with avidin, but $d l$-biotin has half the activity of natural biotin (Emerson, 1945), and $l$-biotin is apparently inactive.

\section{d-Pantothenic Acid}

A few suggestions are to be found in the literature concerning a possible part played by this vitamin in metabolic processes.<smiles>CCC(C)(C)C=CC(=O)NCCC(=O)O</smiles>

Williams and his colleagues (McBurney, Bollen and Williams, 1935) have shown that pantothenic acid stimulates carbohydrate deposition by the green plant without affecting its nitrogenous constituents. Glycogen storage in yeast is increased on incubation with pantothenic acid (Pratt and Williams, 1939). Yeast grown on a medium poor in pantothenate has a low fermenting ability which is increased by application of the vitamin (Williams, Mosher and Rohrmann, 1936). The accelerating action of pantothenate on fermentation by deficient cells is accompanied by a binding of the vitamin to some constituent in the cells (Teague and Williams, 1942), but the vitamin has no effect on formentation by dialysed yeast maceration juices. Its effect on the metabolism of Proteus morganii has been studied (Dorfman, Berkman and Koser, 1942), and the results suggest that it may play some part in pyruvate metabolism. So far the indication is that the vitamin is concerned with some phase of carbohydrate metabolism, but it is difficult to connect this at present with such vol. 4, 1946] 
physiological properties as preventing greying of the hair, with which the vitamin seems to be associated.

\section{Refarences}

Auhagen, E. (1931). Hoppe-Seyl. Z. 204, 149.

Auhagen E. (1932). Hoppe-Seyl. Z. 209, 20.

Axelrod, A. E. and Elvehjem, C. A. (1941). J. biol. Chom. 140, 725.

Axelrod, A. E., Sober, H. A. and Elvehjem, C. A. (1940). J. biol. Chem. 134, 749.

Baddiley, J. and Gale, E. F. (1945). Nature, Lond., 155, 727.

Ball, E. G. (1939). J. biol. Chem. 128, 51.

Banga, I., Ochoa, S. and Peters, R. A. (1939, 1). Biochem. J. 33, 1109.

Banga, I., Ochoa, S. and Peters, R. A. (1939, 2). Nature, Lond., 143, 764.

Banga, I., Ochoa, S. and Peters, R. A. (1939, 3). Nature, Lond., 144, 74.

Barron, E. S. G. and Lyman, C. M. (1939). J. biol. Chem. 127, 143.

Barron, E. S. G., Lyman, C. M., Lipton, M. A. and Goldinger, J. B. (1941, 1). $J$. biol. Chem. 141, 957.

Barron, E. S. G., Lyman, C. M., Lipton, M. A. and Goldinger, J. B. (1941, 2). J. biol. Chem. 141, 975 .

Benoy, M. P. and Elliott, K. A. C. (1937). Biochem. J. 31, 1268.

Braunstein, A. E. and Asarkh, R. M. (1945). J. biol. Chem. 157, 421.

Burk, D., Winzler, R. J. and du Vigneaud, V. (1941). J. biol. Chem. 140, xxi.

Corran, H. S., Dewan, J. G., Gordon, A. H. and Green, D. E. (1939). Biochem. J. $33,1694$.

Corran, H. S., Green, D. E. and Straub, F. B. (1939). Biochem. J. 33, 793.

Davies, R. (1943). Biochem. J. 37, 230.

Dewan, J. G. and Green, D. E. (1938). Biochem. J. 32, 626.

Dorfman, A., Berkman, S. and Koser, S. A. (1942). J. biol. Chem. 144, 393.

Du Vigneaud, V. (1942). Science, 96, 455.

Ellinger, P. and Koschara, W. $(1933,1)$. Ber. dtsch. chem. Ges. 66, 315.

Ellinger, P. and Koschara, W. (1933, 2). Ber dtsch. chem. Ges. 66, 808.

Ellinger, P. and Kosehara, W. (1933, 3). Ber. dtsch. chem. Ges. 66, 1411.

Ellinger, P. and Koschara, W. (1934). Nature, Lond., 133, 553.

Elvehjem, C. A., Madden, R. J., Strong, F. M. and Woolley, D. W. (1937). J. Amer. chem. Soc. 58, 1767.

Elvehjem, C. A., Madden, R. J., Strong, F. M. and Woolley, D. W. (1938). J. biol. Chem. 123, 137.

Elvehjem, C. A., Woolley, D. W., Strong, F. M. and Madden, R. J. (1938). J. biol. Chem. 124, 715 .

Emerson, G. A. (1945). J. biol. Chem. 157, 127.

Euler, H. v., Adler, E. and Günther, G. (1937). Hoppe-Seyl. Z. 249, 1.

Fuler, H. v., Adler, E., Günther, G. and Das, N. B. (1938). Hoppe-Seyl.Z. 254, 61.

Euler, H. v., Albers, H. and Schlenk, F. $(1936,1)$. Hoppe-Seyl. Z. 237, 1 .

Euler, H. v, Albers, H. and Schlenk, F. $(1936,2)$. Hoppe-Seyl. Z. 240, 113.

Euler, H. v. and Hellström, H. (1938). Hoppe-Seyl. Z. 252, 31 .

Fischer, F. G. and Eysenbach, H. (1937). Liebigs Ann. 530, 99.

Funk, C. $(1913,1)$. J. Physiol, 46, 173.

Funk, C. $(1913,2)$. Brit. med. J. i, 814.

Gale, E. F. and Epps, H. M. R. (1942, 1). Biochem. J. 36, 600.

Gale, E. F. and Epps, H. M. R. (1942, 2). Biochem. J. 36, 619.

Gale, E. F. and Epps, H. M. R. (1943). Nature, Lond,, 152, 327.

Gavrilescu, N., Meiklejohn, A. P., Passmore, R. and Peters, R. A. (1932). Proc. roy. Soc. $(B), 110,431$.

Green, D. E. (1936). Biochem. J. 30, 2095.

Green, D. E., Herbert, D. and Subrahmanyan, V. $(1940,1)$. J.biol. Chem. 135, 795.

Green, D. E., Herbert, D. and Subrahmanyan, V. (1940, 2). J. biol. Chem. 138, 327.

Green, D. E., Leloir, L. F. and Dewan, J. G. (1937). Biochem. J. 31, 934.

Green, D. E., Moore, D. H., Nocito, N. and Ratner, S. (1944). J.biol. Chem. 156, 383.

Green, D. E., Westerfeld, W. W., Vennesland, B. and Knox, W. E. (1942). $J$. biol. Chem. 145, 69.

Gunsalus, I. C. and Bellamy, W. D. $(1944,1)$. J. Bact. 47, 413. 
Gunsalus, I. C. and Bellarny, W. D. $(1942,2)$. J. biol. Chem. 155, 357.

Gunsalus, I. C., Bellamy, W. D. and Umbreit, W. W. (1944). J. biol. Chem. 155, 685 .

György, P., Kuhn, R. and Wagner-Jauregg, T. (1934). Hoppe-Seyl. Z. 223, 241.

Haas, E., Horecker, B. L. and Hogness, T. R. (1940). J. biol. Chem. 136, 747.

Harris, S. A. and Folkers, K. (1939). J. Amer. chem. Soc, 61, 1245.

Hawthorne, J. R. and Harrison, D. C. (1939). Biochem. J. 33, 1573.

Karrer, P., Schöpp, K. and Benz, F. (1935). Helv. chim. Acta, 18, 426.

Karrer, P., Schwarzenbach, G., Benz, F. and Solmssen, U. (1936). Helv. chim. Acta, 19, 811.

Kinnersley, 'H. W., O'Brien, J. R. and Peters, R. A. (1935). Biochem. J. 29, 2369.

Klein, J. R. and Kohn, H. I. (1940). J. biol. Chem. 136, 177.

Knight, B. C. J. G. (1937). Biochem. J. 31, 731 .

Kohn, L. J. and Elvehjem, C. A. (1936). J. Nutrit. 11, 67.

Krampitz, L. O. and Werkman, C. H. (1941). Biochem. J. 35, 595.

Krebs, H. A. (1937). Biochem. J. 31, 661.

Kubowitz, F. and Lüttgens, W. (I94I). Biochem. Z. 307, 170.

Kuhn, R., György, P. and Wagner-Jauregg, T. $(1933,1)$. Ber. dtsch. chem. Ges. $66,317$.

Kuhn, R., György, P. and Wagner-Jauregg, T. (1933, 2). Ber. dtsch. chem. Ges. 66, 576 .

Kuhn, R., György, P. and Wagner-Jauregg, T. (1933, 3). Ber. dtsch. chem. Ges. 66, 1034 .

Kuhn, R., Reinemund, K., Kaltschmitt, H., Strobele, R. and Trischmann, H. (1935). Naturwissenschaften, 23, 260.

Kuhn, R. and Rudy, H. (1936). Ber. dtsch. chem. Ges. 69, 2557.

Kuhn, R., Westphal, K., Wendt, G. G. and Westphal, O. (1939). Naturwissenschaften, 27, 469.

Lichstein, H. C., Gunsalus, I. C. and Umbreit, W. W. (1945). J. biol. Chem. 161, 311.

Lipmann, F. (1937). Enzymologia, 4, 65.

Lipmann, F. (1939). Nature, Lond., 143, 436.

Lipmann, F. (1941). Advanc. Enzymol. 1, 99.

Lipton, M. A. and Elvehjem, C. A. (1941). Nature, Lond., 145, 226.

Lohmann, K. and Schuster, P. (1937). Biochem. Z. 294, 188.

Long, C. (1938). Biochem. J. 32, 1711.

Long, C. and Peters, R. A. $(1939,1)$. Biochem. J. 33, 759.

Long, C. and Peters, R. A. (1939, 2). Biochem. J. 33, 772.

Mann, P. J. G. and Quastel, J. H. (1940). Nature, Land., 145, 856.

Mann, P. J. G. and Quastel, J. H. (1941). Biochem. J. 35, 502.

Martius, C. and Knoop, F. (1937). Hoppe-Seyl. Z. 246, 1.

McBurney, C. H., Bollen, W. B. and Williams, R. J. (1935). Proc. nat. Acad. Sci., Wash., 21, 301.

Michaelis, M. and Quastel, J. H. (1941). Biochem. J. 35, 518.

Miller, D. R., Lampen, J. O. and Peterson, W. H. (1943). J. Amer. chem. Soc. 65, 2369.

Nogelein, E. and Wulff, H. J. (1937). Biochem. Z. 293, 351.

Ochoa, S. (1939). Biochem. J. 33, 1262.

Ochoa, S. (1941). J. biol. Chem. 138, 751.

Ochoa, S. and Rossiter, R. J. (1939). Biochem. J. 33, 2008.

Passmore, R., Peters, R. A. and Sinclair, H. M. (1933). Biochem. J. 27, 842.

Pennington, D. E., Snell, E. E. and Eakin, R. E. (1942). J.Amer. chem. Soc. 64, 469.

Peters, R. A., Rydin, H. and Thompson, R. H. S. (1935). Biochem. J. 29, 53.

Peters, R. A. and Sinclair, H. M. (1933). Biochem. J. 27, 1910.

Pilgrim, F. J. and Elvehjem, C. A. (1944). J. biol. Chem. 156, 256.

Pratt, E. F. and Williams, R. J. (1939). J. gen. Physiol, 22, 637.

Quastel, J. H., Tennenbaum, M. and Wheatley, A. H. M. (1936). Biochem. J. 30, 1668 .

Quastel, J. H, and Webley, D. M. (1941). Biochem. J. 35, 192.

Quastel, J. H. and Webley, D. M. (1942). Biochem. J. 36, 8.

Quastel, J. H. and Wheatley, A. H. M. (1938). Biochem. J. 32, 936.

Quastel, J. H. and Wooldridge, W. R. (1929). Biochem. J. 23, 128.

voL. 4, 1946] 
Rossiter, R. J. (1940). J. biol. Chem. 135, 431.

Rydin, H. (1935). Biochem. J. 29, 860.

Schlenk, F. and Snell, E. E. (1945). J. biol. Chem. 157, 425.

Sealock, R. R., Livermore, A. H. and Evans, C. A. (1943). J. Amer. chem. Soc. 65,935 .

Silverman, M. and Werkman, C. H. (1939). Iowa St. Coll. J. Sci. 12, 107.

Silverman, M. and Werkman, C. H. (1941). J. biol. Chem. 138, 35 .

Sinclair, H. M. (1933). Biochem. J. 27, 1927.

Sober, H. A., Lipton, M. A. and Elvehjem, C. A. (1940). J. biol. Chem. 134, 605.

Still, J. (1941). Biochem. J. 35, 380.

Straub, F. B. (1939). Biochem. J. 33, 787.

Straub, F. B. (1940). Biochem. J. 34, 483.

Suzuki, U., Shimamura, T. and Odake, S. (1912). Biochem. Z. 43, 89.

Teague, P. C. and Williams, R. J. (1942). J. gen. Physiol. 25, 777.

Theorell, H. (1934). Biochem. $Z$. 275, 344.

Theorell, H. (1935). Biochem. Z. 278, 263.

Theorell, H. (1936, 1), Biochem. Z. 288, 317.

Theorell, H. (1936, 2). Nature, Lond., 138, 687.

Theorell, H. (1937). Biochem. Z. 290, 293.

Thompson, R. H. S. (1934). Biochem. J. 28, 909.

Trufanov, A. V. (1941). Biokhimia, 6, 301.

Warburg, O. and Christian, W. (1932). Biochem. Z. 254, 438.

Warburg, $O$, and Christian, W. (1933). Biochem. Z. 266, 377.

Warburg, O. and Christian, W. (1934). Biochem. Z. 274, 112.

Warburg, O. and Christian, W. (1935). Biochem. Z. 275, 464.

Warburg, O. and Christian, W. (1936). Biochem. Z. 287, 291.

Warburg, O. and Christian, W. (1938). Biochem. Z. 298, 150.

Warburg, O. and Christian, W. (1939). Biochem. Z. 303, 40.

Warburg, O., Christian, W and Griese, W. (1935). Biochem. Z. 282, 147.

Weil-Malherbe, H. (1939). Biochem. J. 33, 1997.

Williams, R. J., Mosher, W. A. and Rohrmann, E. (1936). Biochem. J. 30, 2036.

Woods, D. D. and Trim, A. R. (1942). Biochem. J. 36, 501.

\section{Some Recently Characterized Members of the Vitamin $\mathrm{B}_{2}$ Complex}

\section{Mr. F. A. Robinson (Glaxo Laboratories, Ltd., Greenford, Middlesex)}

The best known members of the vitamin $B_{2}$ complex aro riboflavin and nicotinic acid which, together with vitamin $B_{1}$, are responsible for certain clearly defined deficiency diseases. The distinction between these factors and the other members of the vitamin $B_{2}$ complex, which do not appear to be associated with specific deficiency diseases, is not as arbitrary as would appear at first sight, and one of the objects of this discussion is to emphasize the real difference that exists between the two groups.

In the course of work on the isolation of the pellagra preventive factor, concentrates were prepared from liver and yeast which not only cured pellagra in man and blacktongue in dogs, but also certain types of dermatitis in rats and chicks. It was subsequently shown that nicotinic acid or its amide was the pellagra preventive factor, and that this had no effect in rat or chick dermatitis. Elvehjem and Koehn (1935) showed that the ability of the crude concentrates to cure rat dermatitis was due to one factor, factor I or vitamin $B_{6}$, and the effect on chicks to another factor, factor II. Since the former was adsorbed on fuller's earth whilst the latter was not, the two factors were sometimes described as the eluate and filtrate factors, respectively. 